\title{
PENGARUH KETERAMPILAN SOSIAL TERHADAP CYBERBULLYING PADA REMAJA PENGGUNA INSTAGRAM
}

\author{
Fellianti Muzdalifah* \\ Fairuz Zanirah** \\ * Fakultas Pendidikan Psikologi, Universitas Negeri Jakarta \\ *** Fakultas Pendidikan Psikologi, Universitas Negeri Jakarta
}

DOI: https://doi.org/10.21009/JPPP.072.01

\section{Alamat Korespondensi: \\ f_muzdalifah@unj.ac.id}

\begin{abstract}
This study aims to determine the influence of social skills and cyberbullying on adolescent as perpetrator or victim in Instagram. The participants in this study were 156 adolescents aged 18 to 24 years, using Instagram, living in Jakarta. The research method used is quantitative with linear regression analysis one predictor. The instrument of cyberbullying in this research is Revised Cyber Bullying II from Topcu \& Erdu-Baker and the instrument of social skills in this research is Social Skills Inventory from Riggio \& Carney. The results showed that there was no significant influence between social skills and cyberbullying preferences on adolescents who become the perpetrator or the victim in Instagram
\end{abstract}

Keywords

Social skills, Cyberbullying, Adolescent, Instagram.

\section{Pendahuluan}

Remaja merupakan masa peralihan dari masa anak-anak menuju masa dewasa. Pada masa ini individu akan mengalami perubahan fisik, psikis, dan kognitif. Remaja sudah dapat berfikir abstrak seperti halnya orang dewasa dan mulai melepaskan diri dari orang tua untuk melanjutkan peran sosialnya sebagai orang dewasa (Santrock dalam Rizeki, 2012). Seperti halnya yang dijelaskan oleh Havighurst (dalam Rizeki, 2012), remaja biasanya akan mencapai hubungan yang lebih baru dan lebih matang dengan teman sebayanya, mencapai peran sosial, menerima keadaan fisik dan menggunakannya secara efektif, mengharapkan dan mencari perilaku sosial yang bertanggung jawab, mencapai kemandirian emosional dari orang tua dan orang dewasa lainnya. Hal tersebut dapat meningkatkan kebutuhan untuk berinteraksi dengan lingkungan sekitar melalui media, salah satunya adalah media sosial.
Penggunaan media sosial saat ini sangat diminati oleh remaja. Hal tersebut dapat dibuktikan dari hasil riset yang dilakukan oleh Andrew Perrin (2016) bahwa penggunaan media sosial terbanyak berasal dari kalangan remaja akhir hingga dewasa awal. Wan Othman, Apandi, dan Ngah (2016) mendefinisikan media sosial sebagai media atau saluran yang digunakan untuk komunikasi online, interaksi, berbagi konten dan kolaborasi. Media sosial yang mendominasi adalah Facebook, Twitter, Instagram, dan LinkedIn. Alasan utama dari penggunaan media sosial sebagai alat komunikasi untuk menjaga hubungan dengan teman dan keluarga dengan cara lebih mudah dan cepat. Selain memberikan kemudahan dalam berkomunikasi, media sosial juga memiliki dampak negatif bagi penggunanya seperti insomnia, perubahan fisik, rasa inferior, kurang konsentrasi dan kurang produktif (Wan Othman et al., 2016). Menurut We Are Social, data statistik penggunaan media sosial di Indonesia pada November 2015 sebesar 79 juta dengan 


\section{Fellianti Muzdalifah}

Fairuz Zanirah

Instagram sebagai media sosial kedua yang banyak digunakan. Hal serupa juga dibuktikan oleh data hasil survey Taylor Nelson Sofres (TNS) yang menyatakan bahwa sebanyak $89 \%$ pengguna Instagram di Indonesia merupakan individu yang masih berusia muda dan mapan Sebagai media sosial yang cukup diminati, Instagram tentu juga memberikan dampak tersendiri bagi penggunanya diantaranya cyberbullying. Hal tersebut dibuktikan dari hasil survey Ditch The Label (2017) yang menunjukkan bahwa $42 \%$ responden mengalami cyberbullying di Instagram.

Pada dasarnya cyberbullying merupakan salah satu jenis dari bullying yang dilakukan secara berulang. Bullying dilakukan untuk menyakiti atau mengganggu orang lain dan melibatkan ketidakseimbangan kekuatan sehingga individu atau kelompok yang lebih kuat dapat mengganggu individu atau kelompok yang tergolong lemah. Perilaku agresif tersebut berisi ketidakseimbangan kekuasaan baik secara fisik atau secara psikologis (Camfiled dalam Mawardah \& Adiyanti, 2014). Pengertian bullying mengalami perubahan seiring dengan perkembangan zaman seperti adanya tindakan agresi yang dilakukan secara diam-diam seperti bergosip atau menyebarkan informasi mengenai teman sebaya ataupun orang yang tidak dikenal.

Cyberbullying juga diartikan sebagai bentuk intimidasi yang dilakukan pelaku untuk melecehkan korbannya melalui perangkat teknologi. Pelaku menggunakan berbagai cara untuk menyerang korban seperti mengirim pesan menyakitkan dan gambar yang mengganggu dan disebarkan ke orang lain untuk mempermalukan korban. Selain itu, pelaku tidak perlu menunjukkan identitas aslinya. Anonimitas ini membuat pelaku lebih mudah untuk menyerang korban tanpa harus memperlihatkan dirinya dan melihat respon fisik secara langsung dari korban. Efek keterpisahan jarak (distancing) dalam pemanfaatan penggunaan internet oleh para penggunanya, khususnya remaja, sering menyebabkan para pelaku cyberbullying mengatakan hal-hal yang tidak menyenangkan dan menghina dibandingkan dengan apa yang umumnya dilontarkan dalam situasi indimidasi secara langsung (Donegan dalam Rachmatan \& Ayunizar, 2017, Kowalski \& Limber, 2013). Pelaku cyberbullying tidak dapat melihat dampak Cyberbullying terjadi karena beberapa peran yang terlibat seperti pelaku, korban, pelaku kasus ini dapat terjadi secara berulang seperti sebuah siklus (Kowalski et al., 2014) sekaligus korban, dan individu dari korban secara langsung (Kowalski, Giumetti, Schroeder, \& Lattanner, 2014). yang tidak terlibat motif dasar dari cyberbullying pada remaja tersebut sulit ditemukan. Beberapa remaja berpendapat bahwa melakukan cyberbullying adalah hal yang menyenangkan sedangkan remaja lainnya menganggap bahwa ketika mereka melakukan cyberbullying, mereka hanya ingin menyakiti atau mempermalukan korban (Williams, 2012). Cyberbullying ini juga terkadang dilakukan sebagai respon terhadap putusnya persahabatan atau suatu hubungan. Selain itu, cyberbullying juga terkadang dilakukan karena kebencian dan sebagai suatu respon terhadap traditional bullying (Rahayu, 2012).

Dampak dari adanya fenomena cyberbullying ini memang terbilang cukup besar bagi perkembangan psikologis seseorang khususnya remaja. Korban yang mengalami cyberbullying dapat memunculkan perilaku depresi, kecemasan, ketidaknyamanan, prestasi menurun, kurangnya minat dalam bergaul dengan teman sebaya, dan menghindari lingkungan sosial. Tak hanya itu, korban yang mengalami cyberbullying dalam jangka waktu cukup lama dapat menimbulkan stres berat, hilangnya rasa percaya diri yang dapat membuat korban memiliki perilaku menyimpang seperti mencontek, membolos, kabur dari rumah, minum-minuman keras, dan menggunakan narkoba. Cyberbullying juga dapat menimbulkan adanya pemikiran untuk bunuh diri pada korban (Rifauddin, 2016).

Di Indonesia sendiri kasus cyberbullying ini sudah menjadi hal yang marak terjadi. Studi pendahuluan yang dilakukan oleh Rahayu (2012) menunjukkan bahwa $32 \%$ remaja mengakui pernah melakukan cyberbullying. Bentuk-bentuk cyberbullying yang paling sering dilakukan oleh remaja berupa mengejek atau mengolok-olok korban, memfitnah atau menyebarkan berita tidak baik tentang korban, dan menyebarkan foto atau video memalukan korban. Hal tersebut lebih sering dilakukan remaja melalui jejaring sosial dan pesan teks. Beberapa remaja tersebut menganggap cyberbullying merupakan sebuah hiburan yang dimaksudkan untuk melukai orang lain sedangkan remaja lainnya berpendapat bahwa cyberbullying 


\section{Fellianti Muzdalifah}

Fairuz Zanirah

dilakukan hanya untuk iseng semata sehingga mereka cenderung melakukannya menggunakan teknologi daripada secara langsung. Tak hanya itu, penelitian serupa mengenai cyberbullying pun sudah pernah dilakukan oleh Rachmatan dan Ayunizar (2017) pada remaja SMA di Banda Aceh. Hasil yang didapat dari penelitian tersebut menunjukkan bahwa remaja laki-laki dan perempuan sama-sama berpartisipasi dalam cyberbullying. Hanya saja metode atau pendekatan yang digunakan oleh remaja laki-laki dan perempuan berbeda.

Banyaknya kasus cyberbullying ini sudah tidak dapat dihindari. Faktor-faktor penyebab munculnya cyberbullying pun beragam salah satunya adalah faktor situasional berupa dukungan yang didapatkan dari lingkungan sekitar seperti teman sebaya ataupun yang lainnya (Kowalski et al., 2014). Dalam kehidupan sosial tentu saja remaja membutuhkan kemampuan berinteraksi pada lingkungannya. Kemampuan tersebut dapat diciptakan dengan adanya keterampilan sosial. Menurut Greshman (dalam Savage \& Tokunaga, 2017) keterampilan sosial merupakan perilaku yang dapat dipelajari dan diperlukan individu agar dapat berfungsi secara efektif dan tepat dalam situasi sosial. Hal tersebut dibutuhkan dalam rangka mengadopsi nilai moral dari budaya dan masyarakat (Salkind dalam Nugraini \& Ramdhani, 2016).

Keterampilan sosial memiliki pengaruh yang penting bagi setiap orang. Rendahnya tingkat keterampilan sosial seseorang dapat memengaruhi lingkungan sosial dan lingkungan pertemanannya, terutama saat memasuki masa remaja. Hal tersebut dapat menyebabkan kurangnya kepekaan pada perasaan orang lain dan juga dapat menjadi penghambat dalam membangun relasi dengan teman sebaya (dalam Lapidot-lefler \& Dolevcohen, 2014) sehingga dapat memicu tejadinya cyberbullying. Selain itu, kurangnya keterampilan sosial yang dimiliki individu juga diidentifikasikan sebagai bentuk dasar terjadinya kejahatan agresi secara tidak langsung (Andreou dalam Savage et al., 2017) dan cyberbullying merupakan salah satu contoh dari agresi tidak langsung. Artinya, keterampilan sosial yang dimiliki pelaku ataupun korban cenderung rendah. Berbeda dengan yang dinyatakan oleh Olweus (dalam Savage et al., 2017) bahwa individu yang memiliki keterampilan
Pengaruh Keterampilan Sosial Terhadap

Cyberbullying Pada Remaja Pengguna Instagram

sosial tinggi cenderung menjadi pelaku cyberbullying. Hal tersebut terjadi karena tingginya keterampilan sosial individu dapat membuat persepsi bahwa pelaku memiliki kendali atas korbannya.

Penelitian terkait keterampilan sosial dan cyberbullying pernah dilakukan oleh beberapa peneliti antara lain Savage dkk (2017) yang menunjukkan bahwa keterampilan sosial tidak memberikan pengaruh terhadap cyberbullying. Beda halnya dengan penelitian yang dilakukan oleh Lapidot-lefler dan Dolev-cohen (2014) mengemukakan bahwa remaja akan memiliki keterampilan sosial rendah apabila terlibat dalam kasus cyberbullying. Penelitian yang relevan lainnya juga pernah dilakukan oleh Rizeki (2012) yang didapatkan dari penelitian tersebut serupa dengan penelitian yang sudah dijabarkan sebelumnya yaitu terdapat hubungan yang berbanding terbalik antara keterampilan sosial dengan perilaku agresif.

Berdasarkan data dan sumber penelitian yang ada, dari ketiga sumber penelitian yang relevan tersebut dapat disimpulkan bahwa hasil penelitian yang didapatkan berbeda. Selain itu, beberapa penelitian tersebut juga belum pernah dilakukan pada remaja pengguna Instagram yang mana Instagram merupakan salah satu wadah yang banyak digunakan oleh remaja sekarang. Dengan keterbatasan penelitian mengenai fenomena tersebut menjadikan alasan peneliti untuk menindaklanjuti fenomena ini. Dengan demikian, peneliti ingin mengetahu seberapa besar pengaruh keterampilan sosial terhadap cyberbullying dikalangan remaja pengguna Instagram yang menjadi pelaku atau korban.

\section{Metode Penelitian}

Penelitian yang dilakukan ini termasuk ke dalam penelitian ex-post facto. Artinya, penelitian tersebut dilakukan untuk meneliti suatu kejadian yang telah terjadi dan menindaklanjuti faktorfaktor yang menyebabkan kejadian tersebut. Sedangkan berdasarkan sifat dan jenis data, penelitian ini termasuk kedalam penelitian kuantitatif yang artinya penelitian ini dinyatakan dengan angka dan teknik analisis yang digunakan adalah teknik statistika (Carminnes \& Zeller dalam Sangadji \& Sopiah, 2010). 
Fellianti Muzdalifah

Fairuz Zanirah

Identifikasi Variabel Penelitian

Variabel independen (bebas) merupakan variabel yang memengaruhi variabel lain (Sugiyono, 2011). Dalam penelitian kali ini, variabel independennya adalah keterampilan sosial. Sedangkan, variabel dependen atau yang dapat disebut juga sebagai variabel terikat ini merupakan variabel yang dipengaruhi variabel lain (Sugiyono, 2011). Dalam penelitian kali ini, variabel dependennya adalah cyberbullying.

Populasi dan sampel

Populasi adalah keseluruhan individu yang merupakan subjek penelitian yang dilakukan (Rangkuti, 2015). Dalam penelitian kali ini, populasi yang akan digunakan adalah sekelompok remaja yang menggunakan media sosial Instagram.

Sampel adalah subjek penelitian yang dapat merepresentasikan kondisi populasi sesungguhnya. Dalam penelitian kali ini, sampel yang akan digunakan adalah individu yang memiliki karakteristik sebagai berikut:

a. Remaja berumur 18 sampai 24 tahun

b. Meggunakan media sosial Instagram minimal 6 bulan.

Teknik yang digunakan dalam pengambilan sampel penelitian ini adalah non-probability sampling. Teknik tersebut dipilih karena tidak semua populasi memiliki peluang untuk dijadikan
Pengaruh Keterampilan Sosial Terhadap

Cyberbullying Pada Remaja Pengguna Instagram

sampel penelitian ini. Jenis teknik sampling yang digunakan adalah insidental sampling. Jenis tersebut dipilih karena populasi pengguna Instagram di Jakarta tidak diketahui sehingga peneliti mengambil sampel secar dirasa memenuhi kriteria sampel (Rangkuti, 2015).

\section{Teknik Pengumpulan Data}

Teknik pengambilan data yang digunakan dalam penelitian ini adalah kuisioner yang berisikan beberapa pertanyaan terkait cyberbullying dan keterampilan sosial. Kuisioner tersebut akan disatukan menjadi sebuah booklet dengan tim payungan peneliti guna mempermudah pengisian responden. Responden akan diminta menjawab setiap pertanyaan yang ada pada kuisioner penelitian tersebut tanpa terkecuali. Kuisioner penelitian tersebut akan didistribusikan secara langsung oleh peneliti dan tim payungan.

\section{Instrumen Revised Cyber Bullying Inventory-II}

Instrumen yang digunakan untuk mengukur cyberbullying berasal dari modifikasi alat ukur Revised-Cyber Bullying Inventory II dari Topcu \& Erdur-Baker (2018). Di dalam instrumen tersebut, terdapat 10 pernyataan yang dapat mengukur dua kategori sekaligus. Kategori tersebut adalah cyberbullying dan cybervictimization. Peneliti melakukan modifikasi dalam bentuk memisahkan pernyataran antara dua kategori tersebut kedalam tabel berbeda. Skala yang digunakan pada instrumen ini sebagai berikut:

Tabel 2.1 Skala Instrumen Revised Cyber Bullying Inventory-II

\begin{tabular}{ll}
\hline Skala & Makna \\
\hline & \\
1 & Tidak pernah \\
2 & Sekali \\
3 & $2-3$ kali \\
4 & Lebih dari 3 kali \\
\hline
\end{tabular}

Dari hasil uji coba yang dilakukan menunjukkan bahwa Cronbach's Alpha yang diperoleh pada kategori cyberbullying sebesar 0,70 reliabilitas item cyberbullying sebesar 0,62 dan reliabilitas person cyberbullying sebesar 0,0 . Artinya, reliabilitas secara keseluruhan tergolong cukup reliabel, kualitas item-item dimensi cyberbullying dan kualitas dari respondennya

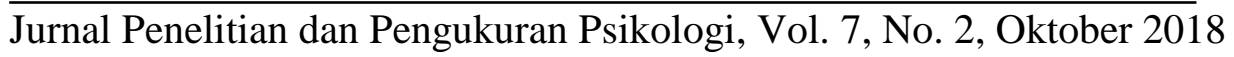




\section{Fellianti Muzdalifah}

Fairuz Zanirah

tergolong lemah atau kurang konsisten dalam memberikan jawaban. Sedangkan pada dimensi cybervictimization diperoleh cronbach alpha sebesar 0,77 , reliabilitas item cybervictimization sebesar 0,81 dan reliabilitas person Cybervictimization sebesar 0,0. Artinya, reliabilitas secara keseluruhan tergolong bagus, kualitas item-item dimensi cybervictimization juga cukup bagus atau konsisten namun kualitas dari respondennya tergolong lemah atau kurang konsisten dalam memberikan jawaban. dan cybervictimizatiion sebesar 0,80 .

Hasil pengukuran yang akan didapatkan berupa 4 peran yaitu pelaku, korban, pelaku sekaligus korban, dan not involved. Tetapi pada penelitian ini hanya membahas lebih dalam pada peran pelaku ataupun korban.
Pengaruh Keterampilan Sosial Terhadap

Cyberbullying Pada Remaja Pengguna Instagram

\section{Instrumen Social Skills Inventory}

Instrumen yang digunakan untuk mengukur keterampilan sosial berasal dari adaptasi alat ukur Social Skills Inventory Manual: Second Edition Manual dari Ronald E. Riggio dan Dana R. Carney (2018). Pada instrumen ini, terdapat 6 dimensi yang mana tiap dimensi memiliki 15 pernyataan. Keenam dimensi tersebut antara lain Emotional Expressivity, Emotional Sensitivity, Emotional Control, Social Expressivity, Social Sensitivity, dan Social Control. Terdapat lima skala yang digunakan pada instrumen ini diantaranya:

Tabel 2.2 Skala Instrumen Social Skills Inventory

\begin{tabular}{cc}
\hline Skala & Makna \\
\hline 1 & Sama sekali tidak seperti saya \\
\hline 2 & Sedikit seperti saya \\
\hline 3 & Mirip dengan saya \\
\hline 4 & Sangat mirip dengan saya \\
\hline 5 & Persis dengan saya
\end{tabular}

Dari hasil uji coba yang dilakukan menunjukkan 73 item dinyatakan valid dan didapatkan reliabilitas instrumen keterampilan sosial sebesar 0,95. Artinya, reliabilitas instrumen keterampilan sosial tergolong bagus sekali

Hasil pengukuran yang akan didapatkan berupa skor total dari tiap-tiap dimensi. Keterampilan sosial dapat dikatakan baik apabila skor yang dihasilkan dari tiap dimensi tersebut seimbang. Apabila terdapat skor yang timpang pada salah satu dimensi dibandingkan dengan dimensi lain maka keterampilan sosial individu tersebut tidak dapat dikatakan baik.

\section{Teknik Analisis Data}

Penelitian kali ini, variabel keterampilan sosial sebagai variabel prediktor dan variabel cyberbullying sebaga variabel kriterium. Berikut ini merupakan persamaan analisis regresi satu prediktor:

$$
\mathbf{Y}=\mathbf{a}+\mathbf{b x}
$$

Y: Variabel yang diprediksi

a: Bilangan konstan

$\mathrm{x}$ : Variabel prediktor

b: koefisien predictor 
Fellianti Muzdalifah

Fairuz Zanirah

\section{Hasil Penelitian dan Diskusi}

Dari hasil penelitian didapatkan 156 responden yang dinyatakan terlibat cyberbullying yang mana

\section{Pengaruh Keterampilan Sosial Terhadap}

Cyberbullying Pada Remaja Pengguna Instagram

58 orang diantaranya cenderung menjadi pelaku dan 98 orang lainnya cenderung menjadi korban. Berikut ini merupakan hasil analisis regresi dimensi cyberbullying dan keterampilan sosial:

Tabel 3.1 Uji Regresi Cyberbullying dan Keterampilan Sosial

\begin{tabular}{llccc}
\hline \multicolumn{1}{c}{ Variabel } & Fhit & Ftab & Nilai & Alpha \\
\hline $\begin{array}{l}\text { Cyberbullying } \\
\text { dan }\end{array}$ & 0,58 & 4,013 & 0,811 & 0,05 \\
$\begin{array}{l}\text { Keterampilan } \\
\text { Sosial }\end{array}$ & & & & \\
\hline
\end{tabular}

Berdasarkan tabel di atas, didapatkan nilai $\mathrm{R}$ square sebesar $0,001(0,01 \%)$. Artinya, besar pengaruh variable keterampilan sosial terhadap cyberbullying pada peneliti ini hanya sebesar $0,1 \%$. Lalu, didapatkan juga didapatkan $\mathrm{F}$ hitung sebesar 0,58 dan $F$ tabel sebesar 4,013 Jika $F$ hitung < F tabel maka dapat disimpulkan bahwa tidak terdapat pengaruh antar kedua variabel dan jika nilai $\mathrm{p}>$ alpha maka pengaruh tersebut bersifat signifikan. Dengan demikian dapat disimpulkan Ho diterima Ha ditolak. Artinya, tidak terdapat pengaruh yang signifikan antara variabel keterampilan sosial dengan dimensi cyberbullying Lalu, berikut ini merupakan hasil analisis regresi dimensi cybervictimization dan keterampilan sosial:

Tabel 3.2 Model Summary Cybervictimization dan Keterampilan Sosial

\begin{tabular}{lccc}
\hline \multicolumn{1}{c}{ Variabel } & R & $\boldsymbol{R}$ Square & $\begin{array}{c}\text { Adjusted } \\
\text { R Square }\end{array}$ \\
\hline $\begin{array}{l}\text { Cybervictimization } \\
\text { dan Keterampilan } \\
\text { sosial }\end{array}$ & 0,039 & 0,002 & $-0,009$ \\
\hline
\end{tabular}

Tabel 3.3 Uji Regresi Cybervictimization dan Keterampilan Sosial

\begin{tabular}{lcccc}
\hline \multicolumn{1}{c}{ Variabel } & F Hit & F $\boldsymbol{t a b}$ & Nilai $\boldsymbol{p}$ & Alpha \\
\hline $\begin{array}{l}\text { Cybervictimization } \\
\text { dan Keterampilan } \\
\text { sosial }\end{array}$ & 0,148 & 0,392 & 0,702 & 0.05 \\
\hline
\end{tabular}

Berdasarkan tabel di atas, didapatkan $\mathrm{F}$ hitung sebesar 0,148 dan F tabel sebesar Jika F hitung < $\mathrm{F}$ tabel maka dapat disimpulkan bahwa tidak terdapat pengaruh antar kedua variabel dan jika nilai $\mathrm{p}>$ alpha maka pengaruh tersebut bersifat signifikan. Sehingga dapat disimpulkan Ho diterima Ha ditolak. Artinya, tidak terdapat pengaruh yang signifikan antara variabel keterampilan sosial dengan dimensi cybervictimization.

Subjek yang menjadi pelaku cenderung berjenis kelamin laki-laki. Hal tersebut sejalan 


\section{Fellianti Muzdalifah}

Fairuz Zanirah

dengan pendapat Li (dalam Kowalski, Giumetti, Schroeder, \& Lattanner, 2014) yang menyatakan bahwa laki-laki cenderung lebih banyak menjadi pelaku cyberbullying. Lalu, jika dilihat dari hasil analisis subjek yang menjadi korban didapatkan bahwa subjek yang berjenis kelamin perempuan lebih banyak menjadi korban dibandingkan pelaku. Hal tersebut juga sejalan dengan hasil penelitian yang dilakukan oleh Lapidot-lefler \& Dolev-cohen (2014) perempuan cenderung lebih banyak menjadi korban cyberbullying.

Lalu, dari hasil analisis subjek yang menjadi pelaku berdasarkan intensitas penggunaan Instagram didapatkan bahwa sebanyak $39.7 \%$ menggunakan Instagram selama 3 sampai dengan 4 tahun lebih, 70,75 menggunakan Instagram setiap hari dalam seminggu, dan 44,8\% menggunakan Instagram selama lebih dari 4 jam. Artinya, individu tersebut memiliki potensi untuk melakukan cyberbullying dikarenakan intensitas penggunaan internet yang sudah mencapai 6 bulan lebih (Topcu \& Erdur-Baker, 2018). Sama halnya dengan intensitas penggunaan Instagram pelaku, subjek yang menjadi korban pun menggunakan Instagram selama lebih dari 6 bulan sehingga memiliki potensi untuk mengalami cyberbullying juga.

Selain itu, bila dilihat dari skor total keterampilan sosial, subjek yang menjadi pelaku cenderung memiliki tingkat keterampilan sosial yang tinggi. Hal tersebut menunjukkan bahwa subjek yang menjadi pelaku dapat menggunakan keterampilan tersebut untuk mengontrol orang lain melalui cyberbullying. Sejalan dengan yang dikatakan oleh Olweus (dalam Savage \& Tokunaga, 2017) bahwa adanya keterampilan sosial yang kuat dapat membuat persepsi bahwa pelaku cyberbullying memiliki kendali atas korbannya. Lalu jika dilihat dari skor total keterampilan sosial pada subjek yang menjadi korban, subjek tersebut cenderung memiliki tangkat keterampilan sosial rendah. Sehingga dapat dikatakan subjek yang menjadi korban lebih mudah dikendalikan oleh orang lain.

Kemudian bila dilihat dari hasil uji hipotesis analisis regresi satu jalur didapatkan bahwa nilai $p$ sebesar 0,405 yang mana nilai tersebut lebih besar daripada 0,05. Sedangkan nilai $F$ hitung pada subjek yang menjadi pelaku sebesar 0,58 yang
Pengaruh Keterampilan Sosial Terhadap

mana nilai tersebut lebih kecil daripada $\mathrm{F}$ tabel. Artinya, tidak terdapat pengaruh

keterampilan sosial terhadap pelaku cyberbullying. Lalu pada hasil uji hipotesis analisis regresi satu jalur pada subjek yang menjadi korban didapatkan bahwa nilai $\mathrm{p}$ sebesar 0,0351 yang mana nilai tersebut lebih besar daripada 0,05 . Sedangkan nilai F hitung pada subjek yang menjadi korban sebesar 0,148 yang mana nilai tersebut lebih kecil daripada $\mathrm{F}$ tabel. Artinya, tidak terdapat pengaruh keterampilan sosial terhadap korban cyberbullying. Dari hasil kedua analisis regresi tersebut dapat disimpulkan bahwa tidak terdapat pengaruh keterampilan sosial terhadap pelaku atau korban cyberbullying.

Dengan demikian, keterampilan sosial tidak dapat dijadikan faktor untuk memprediksi cyberbullying yang terjadi di Instagram. Terdapat faktor-faktor situasional lain yang tidak peniliti bahas lebih lanjut pada penelitian ini seperti dukungan teman sebaya. Menurut Kowalski, Giumetti, Schroeder dan Lattanner (2014) dll, dukungan teman sebaya merupakan salah satu

faktor situasional yang memengaruhi cyberbullying. Dengan adanya dukungan dari teman sebaya, keterampilan sosial yang dimiliki individu pun akan berubah. Remaja mengembangkan kemampuan dalam mengekspresikan perasaan-perasan ataupun ideide yang ada dan pengambilan keputusan pun dapat dipengaruhi oleh teman sebaya (Ghozaly, 2011). Hal tersebut juga diperkuat dengan hasil penelitian yang dilakukan oleh Bester (dalam Ghozaly, 2011) yang menyatakan bahwa remaja akan cenderung lebih banyak menghabiskan waktu dan bergantung dengan kelompok teman sebayanya.

Adapun keterbatasan-keterbatasan yang terdapat pada penelitian ini diantaranya:

a. Kurangnya data konkrit jumlah populasi pengguna Instagram menyebabkan peneliti memiliki hambatan dalam menentukan jumlah sampel yang seharusnya diperlukan oleh penelitian ini sehingga peneliti hanya menggunakan data survey TNS dalam bentuk persentase 
Fellianti Muzdalifah

Fairuz Zanirah

b. Jumlah item yang terlampau banyak pada booklet penelitian menyebabkan responden mengalami kejenuhan dalam mengisi kuisioner.

c. Referensi alat ukur cyberbullying yang tergolong sedikit menyebabkan peneliti menggunakan alat ukur cyberbullying yang tergolong baru. Alat ukur tersebut juga termasuk alat ukur yang belum pernah digunakan oleh peneliti lain di Indonesia sehingga peneliti melakukan penyusunan kembali agar dapat sesuai dengan budaya Indonesia.

\section{Kesimpulan}

Berdasarkan pembahasan sebelumnya, kesimpulan yang dapat diambil adalah tidak terdapat pengaruh antara keterampilan sosial dengan cyberbullying pada remaja pengguna Instagram yang menjadi pelaku ataupun remaja pengguna Instagram yang menjadi korban.

Dengan adanya penelitian ini diharapkan individu khususnya remaja pengguna Instagram dapat meningkatkan kesadaran akan adanya fenomena cyberbullying sehingga individu tersebut tidak lagi terlibat sebagai pelaku ataupun korban cyberbullying. Bagi peneliti yang ingin mengangkat fenomena ini diharapkan dapat meneliti lebih dalam lagi mengenai keterampilan sosial dan cyberbullying, khususnya pada faktor yang mandukung kedua variable tersebut. Peneliti juga berharap penelitian selanjutnya dapat lebih dikembangkan dan dikaitkan dengan variabel psikologis lainnya, sehingga penelitian mengenai keterampilan sosial dan cyberbullying dapat berkembang dan memberikan manfaat kepada masyarakat.

\section{Daftar Pustaka}

Alhabash, S., \& Ma, M. (2017). A Tale of Four Platforms: Motivations and Uses of Facebook, Twitter, Instagram, and Snapchat Among College Students? Social Media + Society, 3(1), 205630511769154. https://doi.org/10.1177/2056305117691544
Pengaruh Keterampilan Sosial Terhadap

Cyberbullying Pada Remaja Pengguna Instagram

Curtis, A. C. (2015). Defining Adolescence. Journal of Adolescent and Family Health, 7(2), 1-39.

https: //scholar.utc.edu/jafh/vol7/iss2/2/

Ditch The Label. (2017). The Annual Bullying Survey 2017. United Kingdom.

Ghozaly, L. F. (2011). Pengaruh Kelompok Teman Sebaya dan Media Massa Terhadap Keterampilan Sosial Atlet Muda di SMA Negeri Ragunan Jakarta. Skripsi. Institut Pertanian Bogor

Gresham, F. M. (1992). Social Skills Rating System. Journal of Psychological Assesment, 100, 196-205

Gresham, F. M., \& Elliott, S. N. (2008). Special Services in the Schools Social Skills Intervention Guide, (December 2014), 3741. https://doi.org/10.1300/J008v08n01

Hurlock, E. B. (1998). Psikologi Perkembangan: Suatu Pendekatan Sepanjang Rentang Kehidupan. Jakarta: Erlangga.

Kowalski, R. M., Giumetti, G. W., Schroeder, A. N., \& Lattanner, M. R. (2014). Bullying in the digital age: A critical review and metaanalysis of cyberbullying research among youth. Psychological Bulletin, 140(4), 10731137. https://doi.org/10.1037/a0035618

Kowalski, R. M., \& Limber, S. P. (2013). Psychological, physical, and academic correlates of cyberbullying and traditional bullying. Journal of Adolescent Health, 53(1), S13-S20. https://doi.org/10.1016/j.jadohealth.2012.09.1 $\underline{8}$

Kowalski, R. M., Limber, S. P., \& Agatston, P. W. (2008). Cyber Bullying. Cyber Bullying: The New Moral Frontier. https://doi.org/10.1002/9780470694176

Langos, C. (2012). Cyberbullying: The Challenge to Define. Cyberpsychology, Behavior, and

$\overline{\text { Jurnal Penelitian dan Pengukuran Psikologi, Vol. 7, No. 2, Oktober } 2018}$ 
Fellianti Muzdalifah

Fairuz Zanirah

Social Networking, 15(6), 285-289. https://doi.org/10.1089/cyber.2011.0588

Lapidot-lefler, N., \& Dolev-cohen, M. (2014). Differences in Social Skills among Cyberbullies, Cybervictims, Cyberbystanders, and Those Not Involved in Cyberbullying. Journal of Child \& Adolescent Behavior, 2(4), 1-9. https://doi.org/10.4172/2375$\underline{4494.1000149}$

Mawardah, M., \& Adiyanti, M. (2014). Regulasi Emosi dan Kelompok Teman Sebaya Pelaku Cyberbullying. Jurnal Psikologi, 41(2014), 60-73.

https://doi.org/https://doi.org/10.22146/jpsi.69 $\underline{58}$

Nugraini, I., \& Ramdhani, N. (2016). Keterampilan Sosial Menjaga Kesejahteraan Psikologis Pengguna Internet 1. Jurnal Psikologi, 43(3), 183-193 https://doi.org/10.22146/jpsi.22 13

Perrin, A. 2015. Pew Research Center. http://www.pewinternet.org/2015/10/08/2 015/Social-Networking-Usage-2005-2015/, diakses 01 Januari 2017.

Patchin, J. W., \& Hinduja, S. (2011). Cyberbullying Prevention and Response. New York: Routledge. https://doi.org/10.4324/9780203818312

Rachmatan, R., \& Ayunizar, S. R. (2017). Cyberbullying pada Remaja SMA di Banda Aceh. Jurnal Insight Fakultas Psikologi Universitas Muhammadiyah Jember, 13(2), 67-79.

Rahayu, F. S. (2012). Cyberbullying Sebagai Dampak Negatif Penggunaan Teknologi Informasi. Information Systems, 8(1), 22-31. Retrieved from http://jsi.cs.ui.ac.id/index.php/jsi/article/view $\underline{1321 / 296}$

Rangkuti, A. A., \& Wahyuni, L. D. (2017). Modul: Analisis Data Penelitian Kuantitatif Berbasis Classical Theory dan Item Response Theory (Rasch Model). Jakarta: Fakultas
Pengaruh Keterampilan Sosial Terhadap

Cyberbullying Pada Remaja Pengguna Instagram

Pendidikan Psikologi, Universitas Negeri Jakarta.

Rifauddin, M. (2016). Fenomena Cyberbullying pada Remaja (Studi Analisis Media Sosial Facebook). Jurnal Ilmu Perpustakaan, Informasi, Dan Kearsipan Khizanah AlHikmah, 4(1), 35-44. https://doi.org/10.24252/kah.v4i1a3

Riggio, R. E., \& Carney, D. R. (2003). Social Skills Inventory Manual $2^{\text {nd }}$ Edition. Mind Garden, Inc.

Riggio, R. E., \& Riggio, R. E. (1986). Assessment of Basic Social Skills. Journal of Personality and Social Psychology, 51(April), 649-660. https://doi.org/10.1037/0022-3514.51.3.649

Rizeki, Z. P. (2012). Hubungan antara Keterampilan Sosial dengan Perilaku Agresif Remaja Siswa Kelas XI SMK Bunda Kandung Jakarta Selatan. Jurnal Penelitian Dan Pengukuran Psikologi, 1(1), 177-182.

Sangadji, E. M., \& Sopiah. (2010). Metodologi Penelitian - Pendekatan Praktis dalam Penelitian. Yogyakarta: Penerbit Andi.

Savage, M. W., Ph, D., Tokunaga, R. S., \& Ph, D. (2017). Computers in Human Behavior Moving toward a theory: Testing an integrated model of cyberbullying perpetration, aggression, social skills, and Internet self-efficacy. Computers in Human Behavior, 71, 353-361. https://doi.org/10.1016/j.chb.2017.02.016

Sinadia, A. R., Amelia, R. N., \& Pamungkas, A. Y. (2015). Reliabilitas Kasus Khusus: Reliabilitas Skor Komposit, 1-12.

Spence, S. H. (2003). Social Skills Training with Children and Young People: Theory, Evidence and Practice, 8(2), 84-96.

Sugiyono. (2011). Metode Penelitian Kuantitatif, Kualitatif, dan R\&D. Bandung: Alfabeta, Cv.

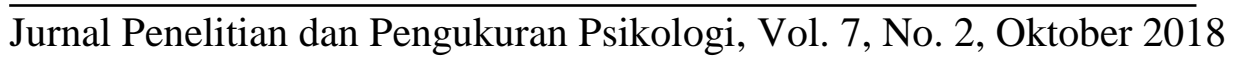


Fellianti Muzdalifah

Fairuz Zanirah

Thompson, R. A. (2006). Promoting Resilience in Children and Adolescents Through Social, Emotional, and Cognitive Skills (Second Ed). New York: Routledge.

Topcu, Ç., \& Erdur-Baker, Ö. (2018). RCBI-II: The Second Revision of the Revised Cyber Bullying Inventory. Measurement and Evaluation in Counseling and Development, 51(1), $32-41$. https://doi.org/10.1080/07481756.2017.1395

Wan Othman, W. R., Apandi, Z. F. M., \& Ngah, N. H. (2016). The uses of social media on student's communication and self concepts
Pengaruh Keterampilan Sosial Terhadap

Cyberbullying Pada Remaja Pengguna Instagram

among TATIUC students. Indian Journal of Science and Technology 9(17). https://doi.org/10.17485/ijst/2016/v9i17/8873 0

Williams, J.(2012). Teens, Sexts, \& Cyberspace : The Constitutional Implications of Current Sexting \& Cyberbullying Laws. William \& Mary Bill of Rights Journal, 20(3), 10171050.

Yang, C. (2016). Instagram Use, Loneliness, and Social Comparison Orientation: Interact and Browse on Social Media, But Don't Compare. Cyberpsychology, Behavior, and Social Networking, $\quad$ 19(12), 703-708

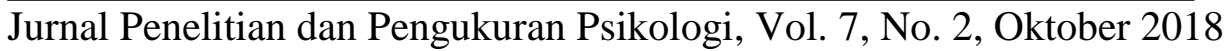

